\title{
Rethinking use and trade of pelagic sharks from Brazil
}

\author{
R.R. Barreto ${ }^{\mathrm{a}, \mathrm{f}, *}$, H. Bornatowski ${ }^{\mathrm{b}}$, F.S. Motta ${ }^{\mathrm{c}, \mathrm{d}}$, J. Santander-Neto ${ }^{\mathrm{e}, \mathrm{f}}$, G.M.S. Vianna ${ }^{1}$, R. Lessa ${ }^{\mathrm{f}}$ \\ ${ }^{a}$ Centro Nacional de Pesquisa e Conservação da Biodiversidade Marinha do Sudeste e Sul do Brasil (CEPSUL/ICMBio), Brazil \\ b Centro de Estudos do Mar, Universidade Federal do Paraná, Pontal do Paraná, Brazil

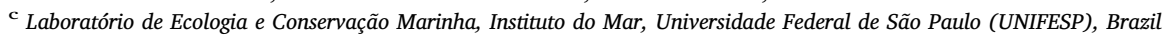 \\ a Laboratório de Pesquisa de Elasmobrânquios, Universidade Estadual Paulista, Campus do Litoral Paulista, São Vicente, Brazil \\ e Instituto Federal de Educação, Ciência e Tecnologia do Espírito Santo, Piúma, Espírito Santo, Brazil \\ ${ }^{\mathrm{f}}$ Laboratorio de Dinamica de Populacoes Marinhas (DIMAR), Departamento de Pesca e Aquicultura (DEPAq), Universidade Federal Rural de Pernambuco, Brazil
}

\begin{abstract}
A B S T R A C T
Brazil currently ranks as the 11th producer and 1st importer of shark meat around the world. Data available from the FAO software FishStatJ along with data from regional sources, such as governmental bulletins, scientific papers, gray literature and internet were revisited to identify the main issues surrounding pelagic shark fisheries, trade and consumption in the largest country in South America. Among the main findings, it was noted that Brazil has not properly collected fishery statistics since 2007, that many species of threatened sharks are freely landed and traded even though it is prohibited by local legislation and/or international recommendations (regional fisheries management organizations). The blue shark (Prionace glauca) is the most frequently recorded shark in the official bulletins and is currently a locally targeted species. Additionally, the significant imports of this species from 23 other countries that also provide fins for Asia has drawn attention in recent decades. Regarding consumption, shark is considered to be low-value seafood compared to more common fish, such as groupers and snappers, and most Brazilians actually do not know that they are eating sharks. At present, the proportion of threatened elasmobranchs (in which sharks are included) in Brazil (33\%, of 145 species) exceeds the global rate identified for the group (25\%), and, until the present moment, no measure related to the management of species has been implemented. As advice, Brazil urgently needs to restructure its fishery information collection systems, management strategies and to tighten sanitary and labeling regulations for the marketing of fish.
\end{abstract}

\section{Introduction}

Sharks are characterized by a peculiar life history, such as late sexual maturity, low fecundity, slow growth, site fidelity, and the formation of reproductive aggregations, which are features that make them susceptible to human impacts and prevent their recovery after shifts in mortality rates [63]. In commercially exploited species, or those incidentally caught, these traits have been associated with overexploitation and an elevated risk of extinction [60]. Because of a full global market with an increased demand for shark products (fins and meat, [25] plus high levels of unregulated bycatch and IUU (Illegal, Unreported and Unregulated Fishing), [75], the International Union for Conservation of Nature (IUCN) considers sharks among the most threatened vertebrates on earth $[13,24,43,46]$.

Large oceanic sharks, as the blue shark (Prionace glauca), shortfin mako (Isurus oxyrinchus), white-tip shark (Carcharhinus longimanus) and others, are highly migratory species that have no direct relation to the sea floor, spending most of their life cycle in the open ocean, being susceptible to multiple fishing fleets [29]. According to the literature, these species are doubly in jeopardy because of their large body size and because of the high value of their body parts (fins) in international markets [30,53].

Shark fins are among the most expensive seafood types in the world used to make a soup that is a symbol of wealth and luxury in Chinese communities established in different parts of the world [69]. As has been observed for terrestrial vertebrates with similar life history traits that are victims of the illegal wildlife trade-such as tigers prized for their penises and rhinos prized for their horns-the high value of fins increases fishing even if the species is threatened and/or rare [53]. According to the IUCN, among the 16 main species of highly migratory sharks, 14 are facing a heightened risk of extinction (i.e., "Threatened" or "Near Threatened"), with fin trade as the main threat $[29,30]$.

\footnotetext{
* Corresponding author at: Centro Nacional de Pesquisa e Conservação da Biodiversidade Marinha do Sudeste e Sul do Brasil (CEPSUL/ICMBio), Brazil.

E-mail address: rodrigorpbarreto@gmail.com (R.R. Barreto).

${ }^{1}$ G.M.S. Viannaa is an independent researcher.
} 
In response to the first shark population declines and the low taxonomic resolution, or even low rate of inclusion in fishery statistical reports, since the mid-1990s, regional fisheries management organizations (RFMOs) have implemented initiatives to ban finning and improve data reports (Appendix S1). Currently, the Food and Agriculture Organization of the United Nations (FAO) reports industrial and smallscale fleets worldwide as being suppliers of the international market for shark fins, while the meat of the same captured sharks is increasingly being diverted along separate channels to meet the demand in growing markets, especially in Brazil [25].

While this combination (bans on finning + growing markets) is seen as positive-contributing to better resolution in fisheries data and also incentivizing the full use of captured sharks, avoiding the waste of carcasses and offering diversified protein for the increasing demand for food-the number of sustainable fisheries in this group worldwide is still low and may occur only in specific areas of the USA, Canada and Australia (countries with a robust investment in management infrastructure) for some small and medium-sized species [23,68], whose life history tends to be more flexible than that of large sharks [71]. Moreover, most pelagic sharks are highly migratory and wide-ranging, requiring international engagement to properly monitor and manage fisheries.

Because pelagic sharks are predominantly top predators, declines in their abundance may entail impacts on marine ecosystems $[34,41,61,62,72]$. In the northwest Atlantic, Mediterranean and Australia, these sharks play an important role in controlling the abundance and behavior of "mesopredators", such as smaller sharks and rays, which in turn are responsible for the control of prey occupying lower trophic levels within "food webs" $[34,61]$. While the need to reevaluate the effects of predator removal has been recently discussed [40], mainly for particular ecosystems $[37,66]$, there is a consensus that marine predators should be properly managed for the maintenance of demographic persistence, density and risk-driven ecological processes $[41,72]$.

With continental proportions ( $8400 \mathrm{~km}$ of coastline), Brazil is the fifth largest country and eighth largest economy in the world (IMF 2017), which is, in contrast, experiencing its worst phase in relation to fisheries management and, consequently, sustainability of its marine biodiversity and fisheries $[1,28,64]$. At the same time that its fishing management collapsed, the country became the first global shark meat importer according to FAO [25]. While domestic production is unknown [49], information on how Brazilians use sharks is poor [9,10]. In this light, the objective of the present study is to show how Brazil has contributed substantially to the consolidation of the truly global market for shark products established over the past few years. This work is timely, since Brazil are re-discussing the conservation priorities for its marine fauna and fisheries, yet there has been no dedicated national fisheries monitoring program for nearly a decade, compromising data needs for management. Our work will contribute to this effort and increase our understanding of the use and trade of highly jeopardized marine species in a data-poor region and recently identified as one of the biggest shark meat consumer globally.

\section{Methods}

Fishing statistics bulletins published in Brazil by the Ministry of Environment and the Ministry of Fisheries and Aquaculture-MPA were inspected along with scientific papers, gray literature and non-scientific media (newspapers and magazines) to the main fishery, trade, consumption and conservation issues pertaining to highly migratory sharks in Brazil (the fishing statistics bulletins are available at http://www. icmbio.gov.br/cepsul/acervo-digital/37-download/estatistica/111estatistica.html). Brazilian participation in fishery production and global fishery commodities production and trade was analyzed using the software FishStatJ [33], freely available at http://www.fao.org/ fishery/statistics/software/fishstatj/en\#downlApp. FishStatJ provides
Table 1

Species of highly migratory pelagic sharks and conservation status according the IUCN Red List of Threatened Species ${ }^{\mathrm{TM}}$ (global) and Instituto Chico Mendes de Conservacao da Biodiversidade (ICMBio, regional). Threatened $=$ VU, EN and CR; Near Threatened $=$ NT and Data Deficient $=$ DD.

\begin{tabular}{|c|c|c|c|c|}
\hline Family & Specie & Common name & IUCN & ICMBio \\
\hline \multirow[t]{3}{*}{ Lamnidae } & Isurus oxyrinchus & Shortfin mako & VU & NT \\
\hline & Isurus paucus & Longfin mako & VU & DD \\
\hline & Lamna nasus & Porbeagle shark & VU & DD \\
\hline \multirow[t]{2}{*}{ Alopidae } & Alopias supercilosus & $\begin{array}{l}\text { Bigeye thresher } \\
\text { shark }\end{array}$ & VU & VU \\
\hline & Alopias vulpinus & $\begin{array}{l}\text { Common } \\
\text { thresher shark }\end{array}$ & VU & VU \\
\hline Pseudocarchariidae & $\begin{array}{l}\text { Pseudocarcharias } \\
\text { kamoharaii }\end{array}$ & Crocodile shark & NT & DD \\
\hline \multirow[t]{3}{*}{ Sphyrnidae } & Sphyrna lewini & $\begin{array}{l}\text { Scalloped } \\
\text { hammerhead }\end{array}$ & EN & CR \\
\hline & Sphyrna zygaena & $\begin{array}{l}\text { Smooth } \\
\text { hammerhead }\end{array}$ & VU & CR \\
\hline & Sphyrna mokarran & $\begin{array}{l}\text { Great } \\
\text { hammerhead }\end{array}$ & EN & EN \\
\hline \multirow[t]{5}{*}{ Carcharhinidae } & Prionace glauca & Blue shark & NT & NT \\
\hline & $\begin{array}{l}\text { Carcharhinus } \\
\text { falciformis }\end{array}$ & Silky shark & NT & NT \\
\hline & $\begin{array}{l}\text { Carcharhinus } \\
\text { longimanus }\end{array}$ & $\begin{array}{l}\text { Oceanic whitetip } \\
\text { shark }\end{array}$ & VU & VU \\
\hline & Carcharhinus signatus & Night shark & VU & VU \\
\hline & Galeocerdo cuvier & Tiger shark & NT & NT \\
\hline
\end{tabular}

access to several FAO datasets (production, exports, imports, re-exports), and those involving any sort of shark product coming from Brazil were selected (Appendix S2). Data on vessels/fishing modalities were analyzed using the site of the Ministry of Fishing and Aquaculture (http://sinpesq.mpa.gov.br) through the General Fishing Register (SisRGP 2015) by initially subsetting vessels registered in coastal municipalities. It is worth mentioning that registering at RGP is compulsory for getting benefits such as subsidies and credits, which makes the RGP representative of the activity. To collect information regarding progress in terms of the conservation of highly migratory sharks in Brazil, the Federal Official Gazette (http://www.icmbio.gov.br/cepsul/ legislacao.html) was inspected. Hereafter, large pelagic sharks should be understood as the group of large-sized species of sharks caught in pelagic fisheries (Table 1).

\section{Results}

\subsection{Fisheries and production}

Brazil (Fig. 1) is currently ranked by the FAO as the 11th shark producer globally and the 17th shark fin exporter (2nd in the South Atlantic for both). In 2007, the year of the latest national bulletin with detailed information regarding catches by species, landings of cartilaginous fishes were $5 \%$ of the total marine production in Brazil [44]. By analyzing the General Fishing Register (SisRGP 2015), we found that in 2014, 23,329 boats were licensed to fish using different types of fishing modalities in the 17 coastal states of Brazil (Appendix S3). These licenses differ from one another concerning the fishing apparatus, target species, vessel size and area of operation. In none of the modalities is any shark species targeted (Appendix S3).

Considering the licenses delivered to longlines and gillnetting vessels, some 8000 boats had interacted with pelagic sharks by 2012 (Appendix S3). This value may be grossly underestimated, since the number of illegal fishing vessels in Brazilian waters is unknown. The states with the largest number of longline licenses were Espírito Santo, Pará, Rio de Janeiro, Ceará, Rio Grande do Norte and Santa Catarina (Fig. 1), whereas the largest number of licenses for gillnets were in Santa Catarina, Maranhão, Sao Paulo and Ceará (Fig. 1).

According to FishStatJ, shark catches peaked in Brazil during the 


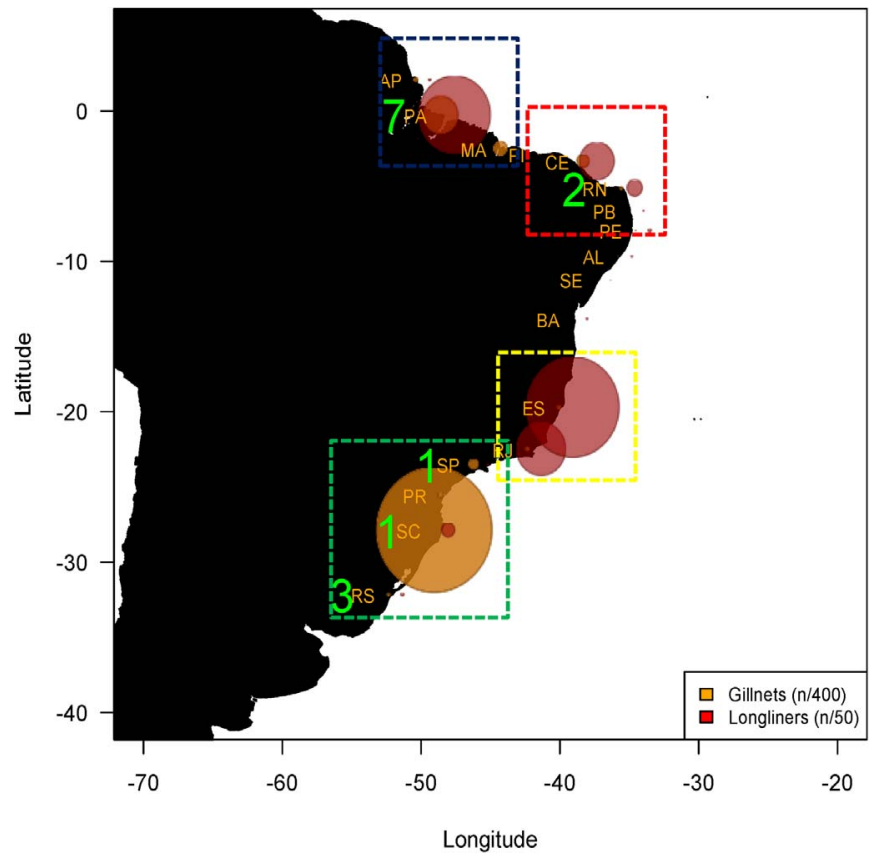

Fig. 1. Map of the Brazilian coast (Southwest Atlantic Ocean) whereas the size of the circles represent the proportional size of fleets that most interact with pelagic sharks in Brazil (incidentally and/or target) by state (source: http://sinpesq.mpa.gov.br/rgp_cms). Red circles $=$ pelagic lines (number of licensed vessels/50), orange circles $=$ gillnets (number of licensed vessels/400). Green numbers refers to the number of enforcement operations dismantling illegal fin trading in Brazil (and their respective locations). Dashed squares mean areas where enforcement operations should be intensified, considering the density of the fleets that interact with medium and large sharks in Brazil nowadays. (For interpretation of the references to color in this figure legend, the reader is referred to the web version of this article.)

first half of the 1990s (approximately 30,000 $\mathrm{t}$ in 1994), declined by half in 1995, increased again after 1998 (to approximately 17,000 t), and stabilized (approximately 20,000 t/year) during the first decade of the 2000s (Fig. 2a, blue line). When analyzing catches of pelagic species, however, an increase in catches from the early 1990s to 2004 $(0-5000 \mathrm{t})$ and from 2004 , a decline to $2500 \mathrm{t}$ by the year 2012 , were recorded (Fig. 2a, red line).

Regarding the taxonomic resolution of the data reported by the FAO, only five species have capture reports at the species level $(P$. glauca, I. oxyrinchus, C. longimanus, C. falciformis and A. superciliosus), and these specifically after 1992 (Fig. 2b). This number differs from the number of species of sharks with information on catches and landings in the official bulletins $[44,59]$. In the bulletins of the states of Sao Paulo and Santa Catarina, major domestic producers and the only states collecting fishery statistics, at least 20 species of sharks have been reported. In any case, the blue shark ( $P$. glauca) is the most caught shark species in Brazil, a fact observed in both regional sources [44,59] as well as in FishStatJ (Fig. 2b).

Identifying the extent of illegal fishing and underreporting of the true catch is challenging in Brazil, as anywhere else. Seizures from illegal shark fishing operations can provide a very conservative estimate of the magnitude of unreported catches in Brazil. When reviewing national publications with reference to fin seizures, 15 enforcement operations were identified as intercepting illegal fin trading, with products obtained by unreported fisheries targeting sharks in Brazilian waters. Together, these operations seized approximately $85 \mathrm{t}$ of illegal fins between 1998 and 2014 (Table 2).

Assuming that dried commercial fins may be $2 \%$ of the total weight of the shark, at least $4250 \mathrm{t}$ of sharks were illegally fished between 1998 and 2014 (approximately 266 t/year). In 2010, 30 t of unreported dried fins ready to be sent to Asia were seized from two fishing companies in northern Brazil, representing $1600 \mathrm{t}$ of shark mass (Table 2). Since the official Brazilian production in 2010 corresponded to 20 thousand tons of sharks, rays, and skates combined (Fig. 2a), the conservative estimate of $1600 \mathrm{t}$ of unreported sharks from unreported cases suggests that total shark fishing is higher than recorded (approximately the same production of $P$. glauca, the most frequent species of shark in Brazilian landings). It is important to note that most of the seizure operations were carried out in the states of Pará (PA) in the north and Rio Grande do Sul (RS) in south of Brazil (Fig. 1, Table 2).

\subsection{Trade and consumption}

Shark meat imports in Brazil have considerably increased since the first half of the 1990s (Fig. 2a, yellow line). Based on the commodity code groups in which Brazilian shark meat trade is recorded, almost all of the shark meat imports correspond to "blue shark, frozen, headed, finned and gutted" carcasses (38.2\%) and "blue shark, frozen, skinless" meat pieces (27.1\%). This means that Brazil imports almost the same amount of blue sharks as its total production for the entire group of cartilaginous fishes (Fig. 2a). Here, it must be mentioned that Brazil absorbed practically all of Uruguay's blue shark production from 2002 to 2012 [25]. Other significant exporters of shark meat to Brazil according to the reviewed data are, in the following order, Spain, Taiwan Province of China and Portugal [25].

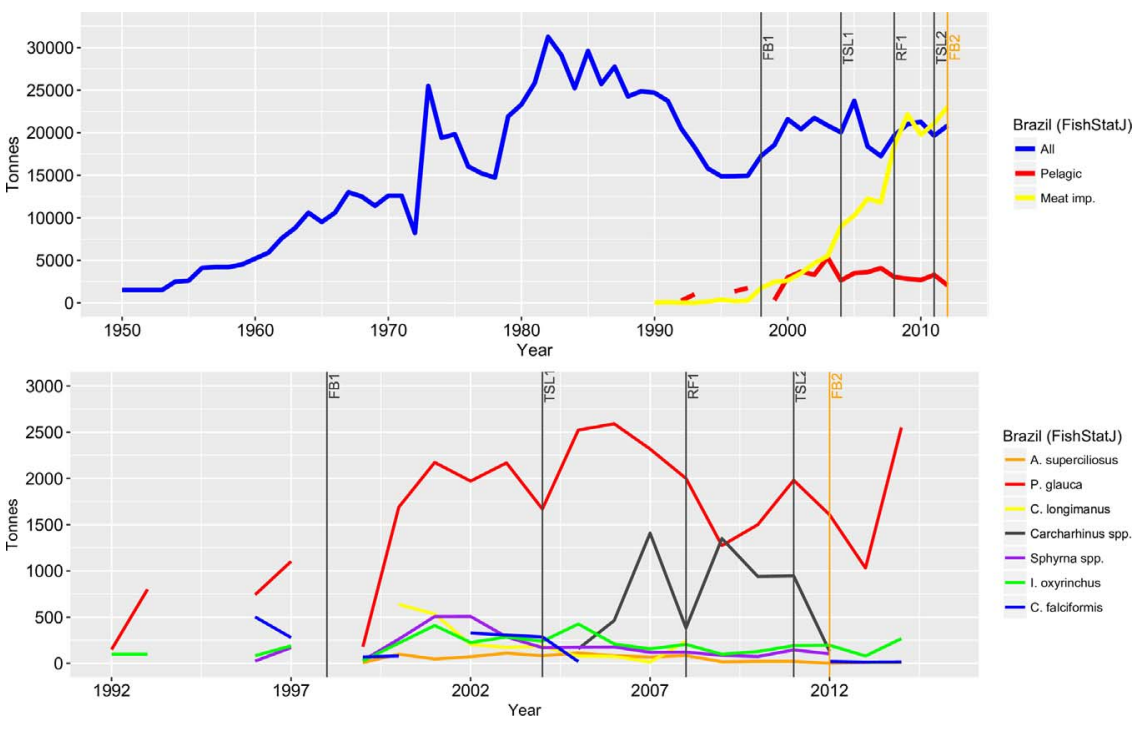

Fig. 2. Brazilian time-series (production and imports) of pelagic sharks highly prized by fins and meat (i.e. commodities), available from FishstatJ application [33]. a: Blue lines mean the sum of all Brazilian cartilaginous fishes reported to FAO (sharks, rays and chimaeras); red line means production of large pelagic sharks (sum of $P$. glauca, I. oxyrinchus, C. longimanus, C. falciformis and A. superciliosus), and yellow line = shark meat imported. b: Production of P. glauca (red), I. oxyrinchus (green), C. longimanus (yellow), C. falciformis (blue) and A. superciliosus (orange). FB1 = first finning ban initiative in Brazil (fins on board should met $5 \%$ of the total weight of the catches); FB2 = second finning ban initiative in Brazil (fins naturally attached to the body); TSL1 = first Brazilian redlist (Brasil, 2004); RF1 = first ICCAT recommendations for non-retention of pelagic shark species from Atlantic Ocean (Sphyrna spp., followed by C. longimanus, Alopias spp. and more recently $C$. falciformis); TSL2 = last redlist (Brazil, 2004). (For interpretation of the references to color in this figure legend, the reader is referred to the web version of this article.) 


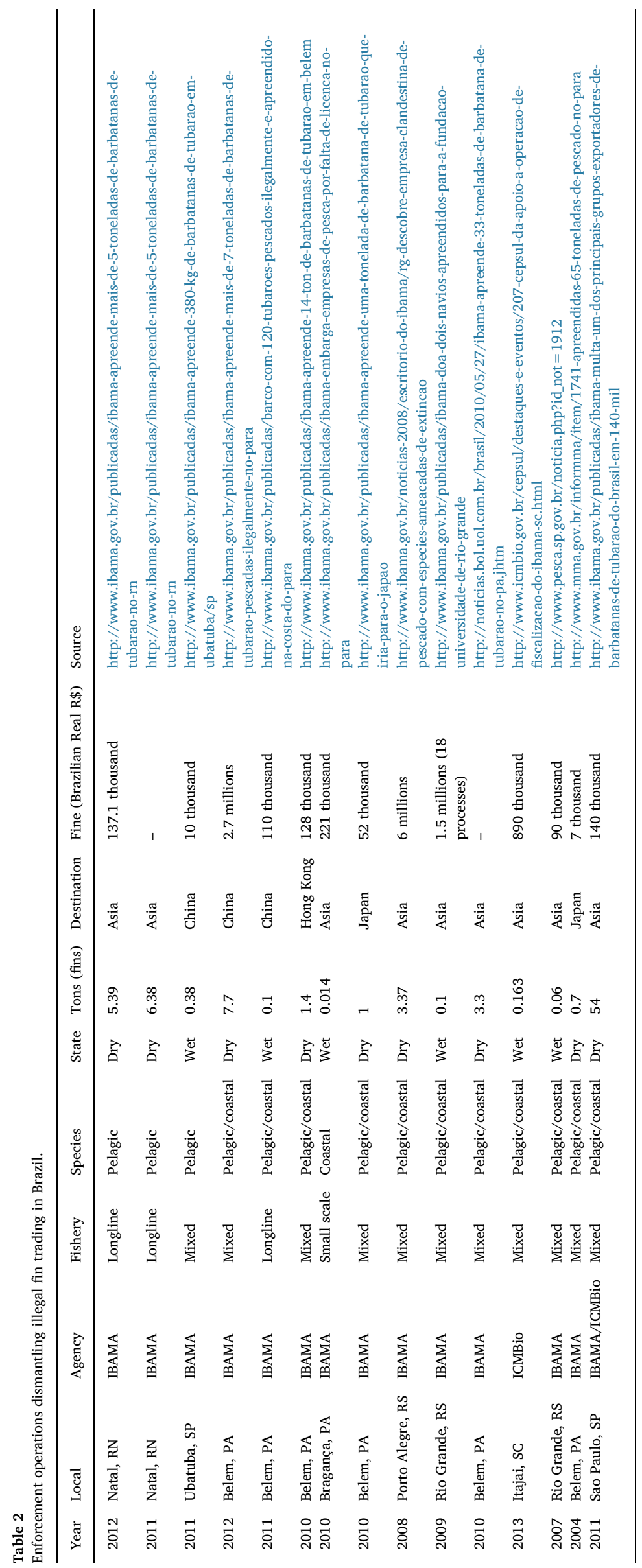


Table 3

Most consumed seafood (and their respective quotations on April 25, 2017) in Brazil according to the Company of Warehouses and General Warehouses of São Paulo (CEAGESP), second largest wholesale fish trade fair in Latin America (third worldwide). Prices are in Brazilian Reais (R \$).

\begin{tabular}{|c|c|c|}
\hline Specie (or better taxonomic info) & Pop. Name* & Average price per kg (Brazilian currency, R\$) \\
\hline Teuthida & Lula Fresca/Fresh squid & 36 \\
\hline Centropomus spp. & Robalo/Common snook & 30 \\
\hline Cynoscion acoupa & Pescada Amarela/Acoupa weakfish & 30 \\
\hline Decapoda & Camarao Ferro/Shrimp & 27 \\
\hline Seriola dumerili & Olho De Boi/ Crevalle jack & 23 \\
\hline Onchorrynchus mykiss & Truta Cativeiro/Raimbow trout & 21 \\
\hline Thunnus spp. & Atum/Tuna & 19 \\
\hline Pseudopercis numida & Namorado/ Sandperch & 17 \\
\hline Seriola quinqueradiata & Olhete/Japanese amberjack & 15 \\
\hline Perciformes & Pargo/Porgy & 14 \\
\hline Pleuronectiformes & Linguado/Flatfish & 14 \\
\hline Pseudoplatystoma corruscans & Pintado Cativeiro/ Spotted sorubim & 12 \\
\hline Anchoviella hubbsi & Manjuba/Anchovy & 11 \\
\hline Sciaenidae & Pescada/Croaker & 11 \\
\hline Carcharhiniformes & Cação/Sharks & 8.5 \\
\hline Hoplias spp. & Traira/Trahira & 7.5 \\
\hline Mugil spp. & Tainha/Mullet & 7.5 \\
\hline Pseudocrenilabrinae & Tilapia Cativeiro/Tilapia & 6.8 \\
\hline Cynoscion guatucupa & Pescada Maria Mole/ Stripped weakfish & 4.8 \\
\hline Urophycis brasilienis & Abrotea/Brazilian codling & 4.5 \\
\hline Cynoscion jamaicensis & Pescada Goete/Jamaica weakfish & 3.8 \\
\hline Micropogonias spp. & Corvina/Whitemouth croaker & 3.8 \\
\hline Prochilodus lineatus & Curimbata/Streaked prochilod & 3.8 \\
\hline Cynoscion spp. & Pescada Tortinha/Weakfish & 3.5 \\
\hline Katsuwonus pelamis & Bonito/Skipjack tuna & 3 \\
\hline Menticirrhus spp. & Betarra/Kingcroaker & 2.5 \\
\hline Micropogonias spp. & Cascote/Croaker & 1.5 \\
\hline
\end{tabular}

Shark meat is broadly sold as "cação", a popular name derived from "cazón" (from the Spanish) to improve consumer acceptance [11]. In coastal states, shark meat is purchased in pieces as "fillet" or "flitch", while in non-coastal cities and large supermarket chains, it is more common to find frozen slices of large carcasses, usually imported from other countries (Appendix S4). A recent study demonstrated that Brazilians do not know they are eating sharks. In a large city in southern Brazil, more than $70 \%$ of surveyed consumers were unaware that "cação" refers to sharks, and more than half of the respondents claimed to have already eaten "cação" but have never eaten sharks or rays [10].

Overall, shark meat is considered low-value seafood (priced around $\mathrm{U} \$ 2.50 / \mathrm{kg}$ ) when compared to more common fish and is usually traded without proper labeling (Table 3). The most common dish made with shark meat in Brazil is called "Muqueca", originally from Espírito Santo and Bahia states, which is a spiced stewed shark recipe of the regional cuisine (Appendix S4). Some of the highlighted qualities of shark meat include the "whiteness" of the flesh and absence of spines [6, 7]. Sharks are also commonly sold as groupers and swordfish to increase the price. For instance, in surveys conducted in southeastern Brazil (the states of São Paulo and Rio de Janeiro), 62\% of fish sold as grouper were actually sharks [32].

The Brazilian government requires offering healthy and varying food to the students of the public network of education [18]. In this light, shark meat have been imported by the government of Brazilian states through public biddings and contracts with local companies to feed children in the public network through the National School Feeding Program (PNAE, [18]. Due to its high population concentration and the fact that it contains the third largest food warehouse in the world, the state of Sao Paulo is likely to be the current largest national consumer and importer of shark meat (CEAGESP 2017).

Despite being both a significant producer and importer of shark meat, to date, there is only two national companies authorized to export shark fins (SECEX 2017) and inaccurate amounts of fins have been historically reported (Appendix S5). Between 1997 and 2001, Brazil did not report any fin exports, although it did report catch production (Appendix S5). We conjecture that this gap may be associated with changes in the fishing industry accompanying the implementation of the first normative against finning in 1998. For most years, the number of fins reported as exports matched those reported as production. However, there have also been cases when exports were reported but not production.

Up to the present moment, little is known concerning the consumption of shark fins in Brazil, although it is not difficult to find restaurants pecialized in Asian gastronomy that serve this delicacy in the larger cities. In any case, this product is not part of the diet of Brazilians under any circumstances, even in poor regions and/or in areas where the demand for animal protein is greater. A recently published report addresses for the first time the relation of artisanal fishers of northeastern Brazil to the market for shark fins [3]. In addition to demonstrating that all of the fins caught by this community are sold for export purposes, the authors also noted that finning still happens frequently in the area [3].

\subsection{Conservation, management and legal framework}

Between 2010 and 2012, the conservation status of cartilaginous fishes was assessed by the Ministry of Environment (MMA) following the IUCN standards, resulting in $33 \%$ of the species being considered as threatened; for an additional $36 \%$ of the species, the limited amount of information available did not permit any sort of assessment. Excessive fishing pressure was identified as the main threat for approximately $90 \%$ of the marine species. The family Sphyrnidae was found to be the most endangered $(100 \%$ of the species in elevated risk categories), followed by carcharhinid sharks ( $56 \%$ of the species). The conservation statuses of all species considered in this study are available in Table 1; for all Brazilian fauna, please consult http://www.icmbio.gov.br/ cepsul/especies-ameacadas.html.

Based on this evaluation, the Ministry of Environment published Ordinance No. 445 [19], which presents the "Official National List of Species of Endangered Species - Fish and Aquatic Invertebrates" in its Annex I and, in its art. 2, states that species classified in the categories Extinct in Nature (EW), Critically Endangered (CR) and Endangered (EN) may be fully protected, and, among other measures, includes a ban on their capture, transport, storage, handling, processing and marketing 
[19]. This is in accordance with the basis of Brazilian environmental legislation, whose Law 9.605 of 1998 and Decree 6.514 of 2008 provide for sanctions against anyone who kills, hunts, collects or uses wildlife specimens, native or migratory, without proper authorization $[14,17]$. For species of commercial interest, Ordinance No. 445, in its 3rd article, provides for the use of species of the Vulnerable category (VU), provided such use is sustainable, regulated, authorized by federal agencies, and minimally meets particular criteria, for example, the implementation of recovery plans [19]. As of 2017, no recovery or management plans for threatened species occurring (directly or indirectly) in Brazilian fisheries have been implemented.

Regarding the legal framework related to the progress of management measures for sharks in Brazil, our analysis of the Official Gazette revealed that at least 20 legislative decrees (among laws, ordinances and others) should guarantee some protection to pelagic sharks in Brazil (Appendix S6). The only pelagic species that have direct restrictions on the minimum catch sizes are Sphyrna lewini and S. zygaena. Interestingly, the minimum catch size for these species is $60 \mathrm{~cm}$ total length (newborn size ranges from 31 to $57 \mathrm{~cm}$ ) (Brasil 2003), [16]. Pelagic species that are prohibited in Brazil, despite those from Ordinance No. 445 and Normative Instruction No. 5 [15] are: Alopias superciliosus, Carcharhinus longimanus and C. falciformis (Appendix S6).

Published in 2014, the National Plan of Action for the Conservation of Endangered Marine Sharks (NPOA-Sharks) aims to mitigate the impacts on marine elasmobranchs threatened by extinction in Brazil and their environments for short-term conservation purposes [20]. Although not directly related to the international proposal of the FAO (IPOA Sharks), some actions are within the international scope. The Brazilian NPOA is composed of nine (9) specific objectives and their respective actions $(n=71)$, whose implementation is foreseen to occur until 2019, with the annual monitoring of progress (Appendix S7). The Brazilian NPOA directly protects elasmobranchs species identified as threatened in the 2004 assessment, being Isogomphodon oxyrhynchus, Rhinobatos horkelii, Cetorhinus maximus, Mustelus schmitti, Squatina guggenheim, S. occulta, Galeorhinus galeus, Ginglymostoma cirratum, $\mathrm{Ne}$ gaprion brevirostris, Pristis pectinata, P. perotteti and Rhincodon typus. However, the proposed actions, if effectively implemented, should also benefit another eight (8) species considered to be overexploited or threatened with overexploitation (Carcharhinus longimanus, C. porosus, C. signatus, Sphyrna lewini, S. tiburo, S. zygaena, Carcharias taurus and Prionace glauca) [15], and, in the near future, the 35 species assessed as threatened between 2010 and 2012 [45].

\section{Discussion}

Although no specific licenses are required to catch sharks, such as there are for tuna, sardines and shrimp, for example (Appendix S3), it seems irrational to maintain that pelagic sharks do not constitute target species for some companies/fleets from Brazil. The blue shark, for example, may account for $49.1-86.1 \%$ of the fish caught with pelagic longlines, depending on the area and season $[5,54,58])$. This species has also been demanded by Brazil (for the meat) more than by any other country in the world, whose volume of blue shark meat imported in 2012 was equivalent to the national production of cartilaginous fish grouped [25]. Likewise, hammerhead sharks (Sphyrna spp.), as well as other sharks with more coastal habits (i.e., Carcharias taurus, Carcharhinus spp.), have been heavily exploited by industrial and artisanal fleets in southern and northern Brazil since the 1980s [47,74]; Lessa et al. Unpublished results).

As all over the world, estimates of the total catch of shark species are uncertain due to discards, finning and a huge level of underreporting [36]; Lessa et al. Unpublished results). Freire et al. [36] showed that the marine catches reported to the FAO by Brazil in 2007 may underestimate the true catch by at least 1.8 -fold, and, specifically for sharks (and rays), there is a considerable loss of taxonomic resolution. These authors noted that at least four shark species frequently reported in statistical bulletins from southern Brazil ("cação-gato", "cação-moro", cação-vaca", and "machote") were added to the category "cações" (sharks) in the national landing bulletins. Another mentioned inconsistency is the inclusion of $10 \mathrm{t}$ originally reported as Isurus oxyrinchus in southern bulletins being attributed to the category "caçãoazul" (Prionace glauca) in the national bulletin (MPA 2010; [36]. Nevertheless, landings of cartilaginous fishes (i.e., sharks and rays) made up $5 \%$ of the Brazilian marine total production during the $2000 \mathrm{~s}$ [44].

The coarse-resolution data that Brazil usually reports to the FAO (e.g., grouping sharks, skates, and rays together and combining fishing gear types; Fig. 2a, blue line) may be masking trends in the catch of pelagic sharks. The red line in Fig. 2a represents the sum of the five species of pelagic sharks in the FAO database (P. glauca, I. oxyrinchus, $C$. longimanus, $C$. falciformis and $A$. superciliosus), where a moderate decline can be observed from 2003. In turn, looking more carefully at the isolated pelagic species (Fig. 2b), it is probable that the abnormal catches of the blue sharks alone (Fig. 2b, red line) may be masking trends in the catch of other pelagic sharks (Fig. 2b).

A recent study that standardized the catch rates of the main pelagic species based on multiple official data sources [5] showed that, except for $P$. glauca, all species of pelagic sharks caught by longlines in Brazil have been systematically declining since 1980 s. By separating FishStatJ data by species (Fig. 2b), it can be seen that the few species of sharks reported by Brazil to the FAO were present in the data analyzed by Barreto et al. [5]. Although the two sources of information are not directly comparable due to multiple uncertainties in both datasets, it is possible to identify abnormal catches of $P$. glauca and a general decline in all other species (Fig. 2b).

Although there are indications that traditional communities in Brazil have consumed sharks in their diets since the precolonization period [50], and some use for the extraction of liver oil during the postWorld War II period, large pelagic sharks could only be captured more frequently through the technological development of offshore fisheries. Thus, according to our review, large pelagic shark meat consumption in Brazil started in the 1970s [52] and is related to FAO initiatives implemented between the end of the 1960s and the first half of the 1980s that offered technical assistance to the Superintendence of Fisheries Development of Brazil (SUDEPE). At that time, several strategies targeted the development of tuna fisheries through the Program of Research and Fisheries Development of Brazil (PDP). Among these was the publication of a booklet strictly focused on the full use of sharks, which were increasingly appearing in national and international fisheries for other species, particularly tuna [52].

Aquatic organisms tend to absorb and accumulate metals, such as mercury and selenium, in their tissues through biotic and abiotic processes [65]. Because these metals are passed through the trophic web and their concentrations increase at each level (biomagnification), large long-lived top predators (i.e., sharks, marine mammals and humans) tend to accumulate the largest amounts of these metals within their respective trophic chains $[2,31,51]$. Brazil has less stringent restrictions in regard to heavy metals in seafood than the European Union, North America, and Asia, allowing products with high levels of heavy metals that would not be marketable elsewhere to be legally commercialized in Brazil [25]. In São Paulo, for example, the largest city and economy in Brazil, $54 \%$ of the shark meat surveyed from different popular markets had mercury concentrations above the acceptable level recommended by the World Health Organization (WHO), which is approximately $1 \mathrm{mg}$ $\mathrm{Hg}^{*} \mathrm{~kg}^{-1}$ [57]. Another study specifically analyzing blue sharks found $70 \%$ of the samples with mercury levels above the recommended level [26].

The institutions responsible for the health of the marine natural heritage, whether in the sense of preserving it or in the sense of exploiting it commercially, have been suffering from the constant political oscillations of the country. Over the past century, for example, responsibility for fisheries management has alternated among the 
different levels of government. In 2003, the Brazilian government created a Special Secretariat for Fisheries and Aquaculture, which in 2009 became the Ministry of Fisheries and Aquaculture (MPA). In 2015, this ministry was defunct, and fisheries management was returned to the Ministry of Agriculture, Livestock and Food Supply (MAPA). In 2017, all fisheries issues were transferred to the Ministry of Development and Foreign Trade (MDIC). According to Dias-Neto and Dias [27], the scope of the problem becomes even greater when it is realized that precisely in the period during which fisheries management occupied the highest status in the country's public administration, the period that observed the creation of the MPA, there was a major disruption of statistical data generation systems and continuous research information.

Since its publication, Ordinance No. 445 (2014a) has been a constant target of diverse discussions, including lawsuits that suspended its effects for a considerable period of time. In June 2015, the ordinance was suspended for the first time and was restored in June 2016; it was suspended again in August 2016 and once again became valid in January 2017. From the moment of its publication in 2014, the ordinance has been suspended for more than a year and a half between 2014 and 2017. In addition, there were also suspensions of the effects of this ordinance for some species in particular [21,22]. Since the release of fishing regulations for some species that had been protected until that time $[21,22]$, it has been observed that the manifestations of the fishing sector have intensified. The dissatisfaction with the restrictions of Brazil's environmental legislation for threatened species (which does not permit the shipment or marketing of threatened species) has been promoted through videos showing mass discards of elasmobranchs and other fragile species that have been broadcasted on various social media outlets, such as YouTube and WhatsApp (Appendix S9). In July 2017, the Ministry of the Environment, responding to multiple requests from the productive sector, released the commercial exploitation of species classified as vulnerable (VU) until July 2018, a period that should be used to build management measures.

Currently however, the country is experiencing a tense climate between the parties involved in the collection of scientific information on fisheries. Many fishing companies and even fishermen, as a form of protest over how the ordinance was promulgated, have made it difficult for researchers to access their fishery data. Evidence also indicates that some Brazilian traders are opening companies in adjacent countries, for example, Uruguay and Guiana, to circumvent inspection and process species that were considered threatened by Ordinance No. 445 [19]. In Brazil, it is not a crime to import threatened species, with the exception of those that are on the appendix one of the CITES list.

Brazil is signatory of the Convention on Biological Diversity (CBD), Convention on International Trade in Endangered Species of Wild Fauna and Flora (CITES), and Convention on Migratory Species and endorses both the FAO's Code of Conduct for Responsible Fisheries and the Voluntary Guidelines for Securing Sustainable Small-Scale Fisheries in the Context of Food Security and Poverty Eradication [28]. In addition, the country has also made commitments to the International Commission for the Conservation of Atlantic Tuna (ICCAT) and the Western Central Atlantic Fishery Commission (WECAFC). Among the many commitments assumed within these conventions, the discontinuation of the fishery monitoring programs is perhaps the best example of how far Brazil is from adequately managing its natural heritage and complying with the additional agendas focused on sustainability.

In Brazil, the risk assessment carried out in 2003 [15] resulted in 12 elasmobranch (six sharks) species evaluated as overexploited or threatened with overexploitation. In 2012 [45], conservation statuses were reassessed, and the number of threatened species in the group increased considerably (58 elasmobranchs, 32 sharks). Considering the last assessment in Brazil, the percentage of species evaluated as endangered (33\% of 145 species assessed) is currently higher than the overall IUCN rate for the group (25\%) [30]. With respect to pelagic species, the most emblematic situations are for S. lewini, C. longimanus, and C. signatus, which have declined in their abundances by $95 \%, 88 \%$ and $77 \%$, respectively.

Declining trends of sharks in Brazil are considered to be a consequence of directed fisheries along Brazilian shelves and oceanic areas (Lessa et al., 1997; [12,5,74]). Moreover, despite the information gap, it is known that for a considerable number of species, nursery grounds and reproductive aggregations have been severely affected by uncontrolled fisheries [38]; Motta et al., 2005; [48,55,56,67,74,76]).

Evidence indicates that legislation may not be enough to protect endangered species in Brazil. Fiedler et al. [35], for example, recently demonstrated that numerous pelagic species with restrictions in terms of retention and trade, including the sharks Alopias superciliosus, A. vulpinus, Carcharhinus longimanus, and Galeorhinus galeus, continue to be freely landed and marketed in national territory but that such events are not adequately reported. It is worth mentioning that the restrictions for these species are outside the scope of Ordinance 445 discussed above, since they are either included in previous lists, as is the case of $C$. longimanus and G. galeus, or subject to international recommendations, as is the case for sharks in the genera Alopias and Sphyrna and for C. longimanus, which have recommendations for non-retention and nonmarketing coming from ICCAT and CITES (Appendix S6).

\section{Conclusions}

Even with the limited fishery statistics available, it is becoming clear that the consumption of shark meat in Brazil currently impacts cosmopolitan populations of large pelagic sharks as much as the countries historically involved in the consumption of shark fins. The Brazilian government (structures related to fisheries management in particular) turns a blind eye to such activities, which are extremely profitable to business as well as detrimental to endangered shark species. This situation is complicated by the lack of a national fisheries monitoring program and by the large number of international partners involved (those importing shark meat into Brazil and exporting fins to east Asia). Furthermore, we highlight significant indicators that Brazil's current status among the largest consumer of large pelagic shark meat in the world is the result of the lack of even minimal information provided to the consumer, and by the low prices offered.

The amount of blue shark meat imported by Brazil from multiple partners was similar to the total national production of sharks and rays combined (approximately 21,000 t; Fig. 2a). While this species is being targeted directly by local fishing fleets in order to sustain the rising demand for meat and food, other more fragile and threatened pelagic sharks will continue to be captured. Because the export of shark meat from Brazil to other countries is negligible [25], it is possible that Brazil is currently the largest consumer of shark meat in the world.

While countries such as Brazil, Uruguay, South Africa, and Namibia have been creating favorable conditions for non-coastal fishing fleets to expand in the region, the proper monitoring of fleets (including local ones) has been inconsistent and decentralized. Therefore, it is essential that Brazil and its neighbors restructure and combine their fisheries monitoring programs in order to provide a better basis for sciencebased management and, consequently, the better use of their natural heritage.

Fortunately, there is currently a vast literature that can help Brazil to take advantage of this moment of crisis to reconstruct a more suitable scenario regarding species of its fauna and fisheries, highlighting the studies of Shiffman and Hammerschlag [70] that addressed the preferences of specialists and non-specialists in the sense of conserving sharks. Barker and Schluessel, Godin and Worm, Herndon et al. and Techera and Klein $[39,4,42,73]$, in turn, have recommended several key policies for more effective management regimes. Ultimately, we present in Table 4 some suggestions contextualized to the current reality in Brazil. 
Table 4

Priority actions for the conservation of large pelagic sharks in the western South Atlantic.

\begin{tabular}{|c|c|}
\hline Problem & Recommendation \\
\hline Fishery statistics blackout & $\begin{array}{l}\text { Establishment of fishing terminals at industrial sites, fully incentives to onboard observers program and collaborative monitoring program in } \\
\text { traditional fishing communities and marine protected areas }\end{array}$ \\
\hline Coarse data resolution & Training and periodic updating of technicians in proposed fishing terminals, traditional fishing communities and marine protected areas \\
\hline Illegal fin trading & Increase contingency of environmental enforcement. Expansion and intensification of oversight coverage (in area and number of operations). \\
\hline Mislabeling & $\begin{array}{l}\text { Creation of specific Ordinance for proper labeling in the case of sharks that are sold as frozen fish (as already done for salmon and cod). In the case } \\
\text { of species marketed as fresh fish, promote campaigns of conscious consumption. }\end{array}$ \\
\hline Population declines & $\begin{array}{l}\text { Establishment of time/area fishing closures and large marine protected areas. Prohibition of directed fisheries until data are available to re-evaluate } \\
\text { the conservation status. }\end{array}$ \\
\hline By-catch reduction & Mandatory use of circle hooks in association with nylon monofilament leaders in longline fisheries. \\
\hline Illegal fisheries & $\begin{array}{l}\text { Register again the fishing vessels and colonies of fishers of Brazil. Extension of the national vessel-tracking program. Creation of a communication } \\
\text { network between coastal states and fisheries management bodies. }\end{array}$ \\
\hline Inefficient legal framework & $\begin{array}{l}\text { Revision of legal framework based on readily available data. Economic incentives for enforcement agencies. Fishing licensing linked to good } \\
\text { practices, counterparts for fishing monitoring and compliance with fishing rules and regulations }\end{array}$ \\
\hline
\end{tabular}

\section{Acknowledgements}

Authors are grateful to the National Council of Technological and Scientific Development (CNPq) and the Coordination for the Improvement of Higher Education Personnel (CAPES) for the grants: 350159/2016-5 (CNPq, Rodrigo Barreto); 303251/2010-7 (CNPq, Rosangela Lessa) and (CAPES, Hugo Bornatowski). We give special thanks to Drs: Shelley Clarke, James Nienow, Francesco Ferretti, Roberta Aguiar dos Santos, Jorge Kotas, Harry Boos, Walter Steenbock and Fernando Fiedler for making important comments on the preliminary version of this manuscript and the anonymous referees and editor whose comments greatly improved this study.

\section{Appendix A. Supporting information}

Supplementary data associated with this article can be found in the online version at http://dx.doi.org/10.1016/j.marpol.2017.08.016.

\section{References}

[1] A.C.Z. Amaral, S. Jablonski, Conservation of marine and coastal biodiversity in Brazil, Conserv. Biol. 19 (3) (2005) 625-631.

[2] L.M. Alves, M. Nunes, P. Marchand, B. Le Bizec, S. Mendes, J.P. Correia, S.C. Novais, Blue sharks (Prionace glauca) as bioindicators of pollution and health in the Atlantic Ocean: contamination levels and biochemical stress responses, Sci. Total Environ. 563 (2016) 282-292.

[3] M.L.V. Barbosa-Filho, E.M. Costa-Neto, S. Siciliano, Knowledge and practices of expert fishermen of South Bahia, Brazil, regarding the international shark fin market, Hum. Ecol. (2016) 1-9.

[4] M.J. Barker, V. Schluessel, Managing global shark fisheries: suggestions for prioritizing management strategies, Aquat. Conserv.: Mar. Freshw. Ecosyst. 15 (2005) 325-347, http://dx.doi.org/10.1002/aqc.660.

[5] R.R. Barreto, F. Ferretti, J.M. Flemming, A. Amorim, H. Andrade, B. Worm, R. Lessa, Trends in the exploitation of South Atlantic shark populations, Conserv. Biol. 30 (2016) 792-804.

[6] A. Begossi, N. Hanazaki, M.R. Ramos, Food chain and the reasons for fishfood taboos among Amazonian and Atlantic Forest fishers (Brazil), Ecol. Appl. 14 (2004) $1334-1343$.

[7] A. Begossi, S.V. Salivonchyk, N. Hanazaki, I.M. Martins, F. Bueloni, Fishers (Paraty, RJ) and fish manipulation time: a variable associated to the choice for consumption and sale, Braz. J. Biol. 72 (2012) 973-975.

[8] H. Bornatowski, P.R. Schwingel, Alimentação e reprodução do tubarão-azul, Prionace glauca (Linnaeus, 1758), capturado na costa sudeste e sul do Brasil, Arquivos de Ciências do Mar 41 (1) (2008) 98-103.

[9] H. Bornatowski, R.R. Braga, J.R.S. Vitule, Shark mislabeling threatens biodiversity, Science 340 (6135) (2013) (923-923).

[10] H. Bornatowski, R.R. Braga, C. Kalinowski, J.R.S. Vitule, "Buying a Pig in a Poke": the problem of elasmobranch meat consumption in Southern Brazil, Ethnobiol. Lett. 6 (1) (2015) 196-202.

[11] H. Bornatowski, R.R. Braga, R.P. Barreto, Elasmobranchs consumption in Brazil: impacts and consequences, in: M.R. Rossi-Santos, C.W. Finkl (Eds.), Advances in Marine Vertebrate Research in Latin America, Springer, 2017, pp. 251-262, http://dx.doi.org/10.1007/978-3-319-56985-7_10.

[12] H. Bornatowski, R. Angelini, M. Coll, R.R. Barreto, A.F. Amorim, Ecological role and historical trends of large pelagic predators in a subtropical marine ecosystem of the South Atlantic, Rev. Fish Biol. Fish. (2017), http://dx.doi.org/10.1007/s11160 017-9492-Z.

[13] D. Bradley, S.D. Gaines, Counting the cost of overfishing on sharks and rays, eLife
2014 (3) (2014) e02199, http://dx.doi.org/10.7554/eLife.02199 (2).

[14] Brazil, Presidência da República, Casa Civil. Lei n 9605. 〈http://www.planalto. gov.br/ccivil_03/leis/L9605.htm〉 (Downloaded 27 May 2017), 1998.

[15] Brazil, Ministério do Meio Ambiente, MMA. Instrução Normativa No 05. 〈http:// www.icmbio.gov.br/sisbio/images/stories/instrucoes_normativas/IN05_2004_ MMA_Aquaticosameacados.pdf $>$ (Downloaded 02 October 2016), 2004.

[16] Brazil, Ministério do Meio Ambiente, MMA. Instrução Normativa No 53. 〈http:// www.icmbio.gov.br/cepsul/images/stories/legislacao/Instrucao normativa/2005/ in_mma_53_2005_tamanhominimoespeciesmarinhaseestuarinas_se_s_altrd_in_mma 03_2006.pdf> (Downloaded 03 June 2017), 2005.

[17] Brazil, Presidência da República, Casa Civil. Decreto n 6514. 〈http://www. planalto.gov.br/ccivil_03/_ato2007-2010/2008/decreto/d6514.htm> (Downloaded 27 May 2017), 2008.

[18] Brazil, Presidência da República, Casa Civil. Lei n 11947. 〈https://www.fnde.gov. $\mathrm{br} /$ fndelegis/action/UrlPublicasAction.php?Acao = getAtoPublico\&sg1_tipo = LEI\& num_ato $=00011947 \&$ seq_ato $=000 \& v 1 r_{\_}$ano $=2009 \&$ sgl_orgao $=$ NI $>$ (Downloaded 03 June 2017), 2009.

[19] Brazil, Ministério do Meio Ambiente, MMA. Portaria MMA 445. 〈http://www. icmbio.gov.br/cepsul/images/stories/legislacao/Portaria/2014/p_mma_445_2014_ lista_peixes_ameacados_extincao_altrd_p_98_2015.pdf> (Downloaded 02 October 2016), 2014a.

[20] Brazil, Ministério do Meio Ambiente, MMA. Portaria MMA 125. 〈http://www. icmbio.gov.br/portal/images/stories/docs-plano-de-acao/pan-tubaroes/portaria125-2014-aprovacao-tubaroes.pdf> (Downloaded 02 October 2016), 2014b.

[21] Brazil, Ministério do Meio Ambiente, MMA. Portaria n 395. 〈http://www.lex.com. br/legis_27181273_PORTARIA_N_395_DE_1_DE_SETEMBRO_DE_2016.aspx 〉 (Downloaded 02 October 2016), 2016.

[22] Brazil, Ministério do Meio Ambiente, MMA. Portaria n 161. 〈http://www. pescamadora.com.br/wp-content/uploads/Portaria-N-161-de-20-de-abril-de-2017. pdf> (Downloaded 02 October 2016), 2017.

[23] J.K. Carlson, L.F. Hale, A. Morgan, G. Burgess, Relative abundance and size of coastal sharks derived from commercial shark longline catch and effort data, J. Fish. Biol. 80 (2012) (2012) 1749-1764.

[24] D. Bradley, S.D. Gaines, Counting the cost of overfishing on sharks and rays, eLife 2014 (3) (2014) e02199, http://dx.doi.org/10.7554/eLife.02199 (2).

[25] F. Dent, S. Clarke, State of the global market for shark products, FAO Fish. Aquac. Tech. Pap. (2015) 590.

[26] A.C. Dias, J.R. Guimarães, O. Malm, Mercúrio total em músculo de cação Prionace glauca (Linnaeus, 1758) e de espadarte Xiphias gladius Linnaeus, 1758, na costa sulsudeste do Brasil e suas implicações para a saúde pública, Cad saúde pública 24 (2008) 2063-2070.

[27] J. Dias-Neto, J.F.O. Dias, O uso da biodiversidade aquatica no Brasil: uma avaliacao com foco na pesca. Ministério do meio Ambiente, Instituto Brasileiro do Meio Ambiente e dos Recursos Naturais Renováveis (2015) 290.

[28] F. Di Dario, C.B. Alves, H. Boos, F.L. Frédou, R.P. Lessa, M.M. Mincarone, M.A.A. Pinheiro, C.N.M. Polaz, R.E. Reis, L.A. Rocha, F.M. Santana, R.A. Santos, S.B. Santos, M. Vianna, F. Vieira, A better way forward for Brazil's fisheries, Science 347 (6226) (2015) (1079-1079).

[29] N.K. Dulvy, J.K. Baum, S. Clarke, L.J. Compagno, E. Cortés, A. Domingo, S. Fordham, S. Fowler, M.P. Francis, C. Gibson, J. Martínez, J.A. Musick, A. Soldo, J.D. Stevens, S. Valenti, You can swim but you can't hide: the global status and conservation of oceanic pelagic sharks and rays, Aquat. Conserv.: Mar. Freshw. Ecosyst. 18 (5) (2008) 459-482.

[30] N.K. Dulvy, S.L. Fowler, J.A. Musick, R.D. Cavanagh, P.M. Kyne, L.R. Harrison, J.K. Carlson, L.N.K. Davidson, S.V. Fordham, M.P. Francis, C.M. Pollock, C.A. Simpfendorfer, G.H. Burgess, K.E. Carpenter, D.A. Ebert, C. Gibson, M.R. Heulpel, S.R. Livingstone, J.C. Sanciangco, J.D. Stevens, S. Valenti, W.T. White, Extinction risk and conservation of the world's sharks and rays, Elife 3 (2014) e00590.

[31] O. Escobar-Sánchez, F. Galván-Magaña, R. Rosíles-Martínez, Biomagnification of mercury and selenium in blue shark Prionace glauca from the Pacific Ocean off Mexico, Biol. Trace Elem. Res. 144 (1-3) (2011) 550-559.

[32] F. Estrella, G. Raposo, J. Pascoli, J.G. Gonzalez, F.S. Motta, R.L. de Moura, Comercialização de pescado nas cidades de São Paulo e Rio de Janeiro. Fundação 
SOS Mata Atlântica, Technical Report, 2014, p. 18

[33] FAO, Fishery and Aquaculture Statistics. Global production by production source 1950-2014 (FishstatJ). in: FAO Fisheries and Aquaculture Department [online or CD-ROM]. Rome. Updated 2016. 〈http://www.fao.org/fishery/statistics/software/ fishstatj/en〉, 2017.

[34] F. Ferretti, B. Worm, G.L. Britten, M.R. Heithaus, H.K. Lotze, Patterns and ecosystem consequences of shark declines in the ocean, Ecol. Lett. 13 (2010) 1055-1071.

[35] F.N. Fiedler, D. Port, B.B. Giffoni, G. Sales, F. Fisch, Pelagic longline fisheries in southeastern/south Brazil. Who cares about the law? Mar. Policy 77 (2017) 56-64.

[36] K.M.F. Freire, J.A.N. Aragão, A.R.R. Araújo, A.O. Ávila-da-Silva, M.C.S. Bispo, G. Velasco, M.H. Carneiro, F.D.S. Gonçalves, K.A. Keunecke, J.T. Mendonça, P.S. Moro, F.S. Motta, G. Olavo, P.R. Pezzuto, R.F. Santana, R.A. Santos, I. TrindadeSantos, J.A. Vasconcelos, M. Vianna, E. Divovich, Reconstruction of catch statistics for Brazilian marine waters (1950-2010). fisheries catch reconstructions for Brazil's mainland and oceanic islands, Fish. Centre Res. Rep. 23 (4) (2015) 3-30.

[37] A.J. Frisch, M. Ireland, J.R. Rizzari, O.M. Lonnstedt, K.A. Magnenat, C.E. Mirbach, J.P.A. Hobbs, Reassessing the trophic role of reef sharks as apex predators on coral reefs, Coral Reefs 35 (2016) 459, http://dx.doi.org/10.1007/s00338-016-1415-2.

[38] O.B.F. Gadig, F.S. Motta, R.C. Namora, Projeto Cacão: a study on small coastal sharks in São Paulo, Southeast Brazil, in: P. Duarte (Ed.), Proceedings of the International Conference on sustainable management of coastal ecosystem, Universidade Fernando Pessoa, Porto, 2002(pp. 260-260).

[39] A. Godin, B. Worm, Keeping the lead: how to strengthen shark conservation and management policies in Canada, Mar. Policy 34 (2010) 995-1001.

[40] R.D. Grubbs, J.K. Carlson, J.G. Romine, T.H. Curtis, M.D. McElroy, C.T. McCandless, C.F. Cotton, J.A. Musick, Critical assessment and ramifications of a purported marine trophic cascade, Sci. Rep. 6 (2016) (article 20970).

[41] M.R. Heithaus, A. Frid, A.J. Wirsing, B. Worm, Predicting ecological consequences of marine top predator declines, Trends Ecol. Evol. 23 (4) (2008) 202-210.

[42] A. Herndon, V.F. Gallucci, D. DeMaster, W. Burke, The case for an international commission for the conservation and management of sharks (ICCMS), Mar. Policy 34 (2010) 1239-1248.

[43] M. Hoffmann, The impact of conservation on the status of the world's vertebrates, Science 1194442 (1503) (2010) 330.

[44] M. IBAMA, Estatística da Pesca 2006 BRASIL: Grandes regiões e unidades da Federação, 2008.

[45] ICMBio, Instituto Chico Mendes de Conservação da Biodiversidade, Avaliação do risco de extinção dos elasmobrânquios e quimeras no Brasil: 2010-2012. Available in: 〈http://www.icmbio.gov.br/cepsul/especies-ameacadas.html〉. (Accessed 3 October 2016), 2016.

[46] IUCN. The IUCN Red List of Threatened Species. Version 2017-1. 〈http://www. iucnredlist.org $>$. Downloaded on 12 May 2017, 2017.

[47] J.E. Kotas, A pesca de emalhe e de espinhel-de-superfície na Região Sudeste-Sul do Brasil. Instituto Oceanográfico-USP, 2005.

[48] R.P. Lessa, R.R. Barreto, A.L.C. Quaggio, L.R. Valença, F. Santana, L. Yokota, M.D. Gianetti, Levantamento das espécies de elasmobrânquios capturados por aparelhos-de-pesca que atuam no berçário de Caiçara do Norte (RN), Arquivos de Ciências do Mar 41 (2) (2008) 58-64.

[49] R.P. Lessa, R.R. Barreto, S. Montealegre-Quijano, R.A. Santos, J.E. Kotas, F.M. Santana, C.M. Vooren (Unpublished results). Fisheries and their impact on marine elasmobranchs (sharks and rays) of Brazil.

[50] M.S. Lopes, T.C.P. Bertucci, L. Rapagnã, R. de Almeida Tubino, C. Monteiro-Neto, A.R.G. Tomas, M. Haimovici, The path towards endangered species: prehistoric fisheries in southeastern Brazil, PLoS One 11 (6) (2016) e0154476.

[51] S.A. Lopez, N.L. Abarca, R.C. Meléndez, Heavy metal concentrations of two highly migratory sharks (Prionace glauca and Isurus oxyrinchus) in the southeastern Pacific waters: comments on public health and conservation, Trop. Conserv. Sci. 6 (1) (2013) 126-137.

[52] Z.L. Machado, P.F. de Oliveira Burgos, Pesquisas tecnológicas sobre a industrialização de tubarões-subsídios técnicos para o planejamento de instalações beneficiadoras, 1978.
[53] L. McClenachan, A.B. Cooper, N.K. Dulvy, Rethinking trade-driven extinction risk in marine and terrestrial megafauna, Curr. Biol. 26 (12) (2016) 1640-1646.

[54] S. Montealegre-Quijano, C.M. Vooren, Distribution and abundance of the life stages of the blue shark Prionace glauca in the Southwest Atlantic, Fish. Res. 101 (3) (2010) 168-179.

[55] S. Montealegre-Quijano, A.T. Cardoso, R.Z. Silva, P.G. Kinas, C.M. Vooren, Sexual development, size at maturity, size at maternity and fecundity of the blue shark Prionace glauca (Linnaeus, 1758) in the Southwest Atlantic, Fish. Res. 160 (2014) $18-32$.

[56] F.S. Motta, F.P. Caltabellotta, R.C. Namora, O.B.F. Gadig, Length-weight relationships of sharks caught by artisanal fisheries from southeastern Brazil, J. Appl Ichthyol. 30 (2014) 239-240.

[57] I.C. Morales-Aizpurúa, A. Tenuta-Filho, A.M. Sakuma, O. Zenebon, Mercúrio total em cação comercializado em São Paulo-SP, Brasil, Ciência e Tecnologia de Alimentos 19 (3) (1999) 429-432.

[58] B.L. Mourato, C.A. Arfelli, A.F. Amorim, H.G. Hazin, F.C. Carvalho, F.H. Hazin, Spatio-temporal distribution and target species in a longline fishery off the southeastern coast of Brazil, Braz. J. Oceanogr. 59 (2) (2011) 185-194.

[59] MPA, Boletim Estatístico da Pesca e Aquicultura - Brasil 2010, Minist. da Pesca e Aquicultura (2012) 129 (Brasília/DF).

[60] R.A. Myers, B. Worm, Rapid worldwide depletion of predatory fish communities, Nature 423 (2003) 280-283, http://dx.doi.org/10.1038/nature01610.

[61] R.A. Myers, J. Baum, T. Shepherd, S. Powers, C.H. Peterson, Cascading effects of the loss of apex predatory sharks from a coastal ocean, Science 315 (2007) 1846-1850.

[62] D. Pauly, V. Christensen, J. Dalsgaard, R. Froese, F. Torres, Fishing down marine food webs, Science 279 (5352) (1998) 860-863.

[63] E.K. Pikitch, M.D. Camhi, E.A. Babcock, Introduction to sharks of the open ocean, Sharks Open Ocean.: Biol. Fish. Conserv. (2008) 3-13.

[64] H.T. Pinheiro, F. Di Dario, L.C. Gerhardinger, M.R.S. Melo, R.L. Moura, R.E. Reis, F. Vieira, J. Zuanon, L.A. Rocha, Brazilian aquatic biodiversity in peril, Science 350 (6264) (2015) 1043-1044.

[65] G.M. Rand, P.G. Wells, L.S. McCarthy, Introduction to aquatic ecology. Pp 3-53, in: G.M. Rand (Ed.), Fundamentals of Aquatic Toxicology, Taylor and Francis, London, 1995.

[66] G. Roff, C. Doropoulos, A. Rogers, Y.M. Bozec, N.C. Krueck, E. Aurellado, M. Priest, C. Birrell, P.J. Mumby, The ecological role of sharks on coral reefs, Trends Ecol. Evol. 31 (2016) 395-407.

[67] J. Santander-Neto, R.A. Shinozaki-Mendes, L.M. Silveira, B. Jucá-Queiroz, M.A. Furtado-Neto, V.V. Faria, Population structure of nurse sharks, Ginglymostoma cirratum (Orectolobiformes), caught off Ceará State, Brazil, southwestern Equatorial Atlantic, J. Mar. Biol. Assoc. U.K. 91 (2011), pp. 1193-1196.

[68] C.A. Simpfendorfer, N.K. Dulvy, Bright spots of sustainable shark fishing, Curr. Biol. 27 (2017) R97-R98.

[69] K.H. Shea, A.W.L. To, From boat to bowl: patterns and dynamics of shark fin trade in Hong Kong-implications for monitoring and management, Mar. Policy 81 (2017) 330-339.

[70] D.S. Shiffman, N. Hammerschlag, Shark conservation and management policy: a review and primer for non-specialists, Anim. Conserv. (2016).

[71] S.E. Smith, D.W. Au, C. Show, Intrinsic rates of increase in pelagic elasmobranchs, Sharks Open Ocean.: Biol. Fish. Conserv. (2008) 288-297.

[72] E.K.A. Spiers, R. Stafford, M. Ramirez, D.F.V. Izurieta, M. Cornejo, J. Chavarria, Potential role of predators on carbon dynamics of marine ecosystems as assessed by a Bayesian belief network, Ecol. Inf. 36 (2016) 77-83.

[73] E.J. Techera, N. Klein, Fragmented governance: reconciling legal strategies for shark conservation and management, Mar. Policy 35 (2011) 73-78.

[74] C.M. Vooren, S. Klippel (Eds.), Ações para a conservação de tubarões e raias no sul do Brasil, Sandro Klippel, 2005.

[75] B. Worm, B. Davis, L. Kettemer, C.A. Ward-Paige, D. Chapman, M.R. Heithaus, S.T. Kessel, S.H. Gruber, Global catches, exploitation rates, and rebuilding options for sharks, Mar. Policy 40 (2013) 194-204.

[76] L. Yokota, R.P. Lessa, A nursery area for sharks and rays in northeastern Brazil, Environ. Biol. Fishes 75 (3) (2006) 349-360. 